\title{
ТРАНСФОРМАЦІЯ ПРОФЕСІї ЖУРНАЛІСТА В ЦИФРОВОМУ СЕРЕДОВИЩІ
}

\author{
Вікторія Шевченко \\ Інститут журналістики \\ Киівського національного університету імені Тараса Шевченка, \\ вул. Юрія Іллєнка, 36/1, 02000, Київ, Украӥна \\ e-mail:victoryshe@gmail.com \\ https://orcid.org/0000-0003-1642-1283
}

У статті розглянуто тенденції трансформації професії журналіста, представлено навички, необхідні для роботи в цифровому середовищі. Сучасність змінює вимоги до підготовки матеріалів, заохочує журналістів постійно розвиватися і шукати нові способи подачі інформації, вимагає нестандартного мислення в опрацюванні теми, висвітленні загальновідомих фактів, знання сучасних технологій.

Ключові слова: цифрова журналістика, навички журналіста, фактчекінг, аналітика, великі дані.

У теперішніх умовах розуміння професії журналіста як фахівця, який вміє написати статтю, взяти інтерв’ю чи зняти відео, проаналізувати масив даних, зробити репортаж, тощо, зазнає суттєвих змін. Сучасний журналіст повинен володіти різноманітними професійними навичками, бути багатофункціональним, готовим для виконання будь-якого завдання, освоїти не лише суто журналістські навички, але i бути технічно обізнаним: вміти монтувати відео, обробити фото, створити інфографіку, перевірити достовірність невербального та вербального контенту, здійснити кількісний та якісний аналіз великого обсягу даних, провести розслідування, зверстати сюжет, створити сайт, вести блог, створити мультимедійний контент, захистити свої дані та акаунти.

Традиційно вважається, що завдання журналіста - працювати з текстом, або ж спеціалізуватися на радіожурналістиці, чи тележурналістиці, чи працювати у газеті. Зараз журналіст має бути готовим одночасно створювати матеріал для онлайн-трансляції, короткі повідомлення-анонси оперативної інформації для соціальних мереж, матеріал сайту, друкованого медіа, телепередачі, радіоефіру, тобто зняти фото чи відео гарної якості, записати на диктофон інтерв'ю, зробити інфографіку, i, звісно, написати текст.

Останніми роками з'явилось чимало статей науковців, викладачів університетів щодо оновлення програми підготовки журналістів. Над оновленою професією журналіста розмірковують журналісти-практики, численні організації, які працю-

(C) Шевченко В., 2019 
ють над проектами 3 медіаграмотності проводять дослідження, виявляють якості, необхідні сучасному журналісту. Приміром, «Детектор медіа» опублікував серію матеріалів щодо журналістської освіти в різних країнах [1]: «Журфаки Польщі: інноваційні, та чи відповідають потребам ринку?», «Чи вдалося журналістській освіті в Чехії позбутися радянських підходів?», «Журналістська освіта в Німеччині: розмаїття й неакадемічність», «Болонська система «по-українськи»: мімікрія, лінь та відверта маніпуляція»; про суто українські проблеми: «Університети не повинні бути пасивними й чекати, доки держава щось дасть», спеціальний звіт «Актуальні аспекти реформування журналістської освіти в Україні», «У медійної галузі немає запиту на підготовку кадрів» [2] та ін.

Звісно, освіта журналіста не може відставати від практичної діяльності, тому журналісти та редактори залучаються до навчального процесу, ведуть окремі професійні модулі або дисципліни цілком. І це є суттєвим надбанням навчального процесу, зануренням студентів у справжній редакційний колектив, журналістські будні.

Дослідженням нових викликів професії журналіста займаються міжнародні та українські журналістські спільноти й організації. Серед них варто виділити Міжнародний центр журналістів (ICFJ), Training Center of Google News Lab, Investigative Reporters and Editors, Nieman Journalism Lab, Свропейську обсерваторію журналістики EJO, Інститут Reuters із вивчення журналістики, Незалежну Медіа-Профспілку України (НМПУ), Незалежну асоціацію теле-радіомовників та інші.

Ми поставили за мету виявити головні тенденції трансформації професії журналіста, назвати навички, необхідні для роботи у цифровому середовищі. Відповідно до цього завданнями $є$ : вивчити досвід українських та зарубіжних редакцій та медіаорганізацій; проаналізувати склад редакцій і виявити нові посади з їх функціональними обов'язками; скласти перелік компетентностей журналістів, необхідних для роботи в цифрову епоху, здатність їх виконувати покладені обов'язки, обізнаність у технологічних можливостях, а також спрогнозувати напрями подальшого розвитку журналістської професії.

Результати дослідження. Журналісти виробляють набагато більшу кількість контенту порівняно з попередніми роками. Сучасним журналістам важко конкурувати в оперативності подачі інформації з мільйонами людей, які поширюють всі події, свідками яких стають, в соцмережах. Найбільш важливим тут, на нашу думку, є достовірність наведених фактів, надійне перевірене джерело інформації та оригінальний виклад суті. Величезна кількість різнорідної інформації з різних джерел ускладнює роботу журналіста, оскільки дані та факти необхідно не лише знайти, але і перевірити на достовірність. Для цього існує низка методик і технічних засобів. Достатньо надрукувати неперевірену інформацію, як репутація медіа може отримати важкий удар. Отже, сучасному журналісту перед опрацюванням інформації та підготовкою матеріалу, потрібно ретельно перевірити факти, отримані фото і відеоматеріали, результати опитувань і рейтинги.

Журналіст одноосібно пише текст, працює за камерою, навіть робить підводки, записує звук для радіо, монтує. Результатом такої роботи стає текстова історія, радіопередача, сюжет для телебачення, фотогалерея, кілька кадрів для онлайн. Але, крім цього, журналіст має бути технічно і технологічно обізнаним - знати програми перевірки та аналізу даних, створення візуалізацій, редагування зображень, монтування відео. Сьогодні журналіст - це не лише гуманітарій, творча особистість. 
Як результат трансформації професії журналіста - інший спосіб мислення та звички, знання сучасних технологій збору, верифікації даних, створення інфографіки, відео та аудіосюжетів, опрацювання фото, створення лонгрідів. Журналіст не лише постійно шукає інформацію, він допитливо вивчає все, що стосується теми його публікації, орієнтується в історії питання, знає фахівців та видання, які можуть бути корисні для більш повного розкриття теми, знаходить теми в буденних речах. Як зауважують журналісти $B B C$ : «Часом, ідучи 3 кимось вулицею, він за 500 метрів прогулянки знаходить сотні історій - про кількість сміття, правила паркування, кількість нових машин, дорожніх інспекторів, масове куріння у кафе, оскільки це заборонено на роботі, відкриття чи закриття магазинів, жебраків $з$ цікавою біографією, нове будівництво» [3]. Сучасні умови вимагають не просто зробити сюжет, а й подати його в оригінальному ракурсі, що передбачає ретельну роботу з фактами та даними. Сучасні програмні засоби дозволяють робити цікаві візуалізації, будувати графіки, хмари тегів, наносити на карти потрібні об’єкти. Не надто великих зусиль треба докласти, щоб освоїти програми для створення лонгрідів. Тож журналісти розуміють, що виключно роботи з текстом вже недостатньо.

Журналісти інтенсивно збирають й аналізують дані з усіх можливих каналів, аби не пропустити головного, розумітися в нових трендах, знати якнайбільше в конкретній темі, що, в свою чергу, дає читачам якісний інформаційний продукт. Але не всі вони мають для цього достатньо можливостей й технічних знань. Найскладніша проблема сьогодення - величезні обсяги даних, що виробило термін Big Data, пов'язаний не так $з$ даними, як з технологіями їх обробки. Ця технологія стала необхідною складовою діяльності будь-якого ефективного бізнесу, а медіа сьогодні ним стає. Використання їх у сфері комунікацій покращує результати кампаній i, водночас, дозволяє зекономити бюджет. Великим даним передувало поняття «журналістики даних» [4, C.5], описане у 2011 році на семінарі «MozFest» у Лондоні, що дало принципово новий погляд на способи отримання і відображення контенту.

Нові умови роботи вимагають оновлення штату редакцій з урахуванням цифрових технологій, більшість медіа намагаються перебудувати традиційну роботу журналіста на новий лад. У більшості редакцій переважають журналісти та редактори (82\%), і лише менше чверті (18\%) - це нові штатні працівники 3 так би мовити цифровими функціями (редактор соціальних мереж, виробник цифрового контенту, фахівець з аналітики та інші). Стають популярними нові гібрідні посади, наприклад, редактор історій (створює лонгріди з інтерв’ю, фото, цитатами, словником, хронологією, відео), інфограф (перетворює дані на інфографіку), контент-менеджер (керує потоком новин, відбирає і впорядковує публікації, моніторить новини і виставляє анонсами короткі повідомлення чи анонси майбутніх матеріалів), редактор коментарів (модерує коментарі читачів, вчасно відповідає, спрямовує у потрібному напряму, перевіряє інформацію), продюсер впливу (шукає спосіб найефективніше визначати, залучати та інформувати потрібну аудиторію, впливати на неї), SEO-редактори (оптимізують контент, налагоджують зв'язок між відділами менеджменту та технологій), редактори-аналітики (виводять статистику задля оптимізації графіку публікацій і зв’язку з аудиторією), редактори розсилок (перетворюють випадкових читачів на постійних), редактор соцмереж (згуртовує людей навколо сторінки в соцмережах та скеровує їх на сайт), журналісти-кодери (створюють мультимедійні історії з використанням програмованих скриптів) та інші. Гібридні професії вимагають нових 
навичок та змінюють культуру медійних організацій, навчаючи журналістів та редакторів розмовляти мовами інженерії, маркетингу та дизайну.

Кожна редакція має власні підходи до організації роботи, задля чого створюють нові посади. Так, The Washington Post створила три нові посади в редакції: операційний редактор, редактор продукту та редактор проектів; The Financial Times призначила свого колишнього редактора спецпроектів на посаду керівника відділу цифрової доставки, покликаного розширити межі цифрового сторітелінгу та перетворити творче проектне планування на частину щоденної роботи видання. ВВС ще кілька років тому створила відділ $B B C$ News Labs, мета якого - поєднувати журналістику, дані та технології.

Випускники факультетів журналістики нерідко більш придатні до сучасних цифрових умов діяльності, ніж досвідчені працівники редакцій. Звісно, їм не вистачає досвіду роботи, але вони швидше адаптуються, розуміють тренди, орієнтуються в сучасних медійних технологіях. Проблему могла б виправити мережа шкіл журналістики, в яких журналісти могли б періодично знайомитись з сучасними трендами і технологіями, можливостями ефективної роботи. Дослідження свідчать, що журналісти прагнуть такого навчання, але не мають змоги через завантаженість на роботі та небажання керівництва скерувати їх на таке підвищення цифрової кваліфікації. Лише 40\% служб новин пропонують навчання на власній базі. Старша редакторка $з$ цифрового сторітелінгу The New York Times Чаро Енрикес наголошує, що журналісти більше не можуть обмежуватися написанням тексту, мусять навчитись не тільки знаходити та розповідати історії, а й оцінювати потреби аудиторії на всіх етапах виробництва й поширення контенту та вимірювання його ефективності [5]. Отже, редакціям бажано зробити безперестанне навчання та співпрацю складовими редакційної культури й сприймати витрати на професійний розвиток журналістів як інвестицію, яка допомагає зберегти зв’язок з аудиторією у цифрову добу.

Про те, що журналістам доводиться ставати програмістами, пише Безил Саймон, який поєднує ці дві функції у британській The Times [6]: «журналісти-кодери вже стали незамінними у висвітленні багатьох важливих тем, цей новий тип працівників постає перед дилемою, схожою на вибір між писанням і редагуванням. Деякі журналісти відмовляються ставати редакторами, бо не хочуть припиняти писати, але саме редакторство передбачає більшу відповідальність та вищу зарплатню. Програмісти так само вагаються, чи варто відмовлятись від того, що вони вміють найкраще - програмування». Тобто медіаменеджерам слід створити для журналістів-кодерів можливості кар'єрного зростання без втрати їхньої подвійної професійної сутності, зважаючи на те, що більшість керівних посад у редакціях є традиційно журналістськими, а перед людиною, яка поєднує роботу журналіста і програміста, постає питання кар'єрної перспективи.

Міжнародний центр для журналістів Джорджтаунського університету опитав редакції медіа в 130 країнах на 12 мовах щодо їх технологічної оснащеності та готовності журналістів опановувати технічну складову професії (опрацьовано понад 2700 відповідей) [6]. Виявилось, що лише 5\% журналістів у відділах новин мають технічну освіту, а фахівці з аналітики є рідкісними в редакціях (1\%). Журналісти користуються обмеженим набором цифрових засобів. 323 цифрових методів, за якими проводилося опитування, найбільш популярними є публікація або коментар в соціальних мережах (72\%), цифрова фотозйомка (61\%), залучення аудиторії в соціальних 
мережах (58\%) і поширення контенту на декількох платформах (56 \%) (рис. 1). Цей малюнок цікавий саме своїм переліком цифрових навичок, необхідних для роботи в сучасних медіа.

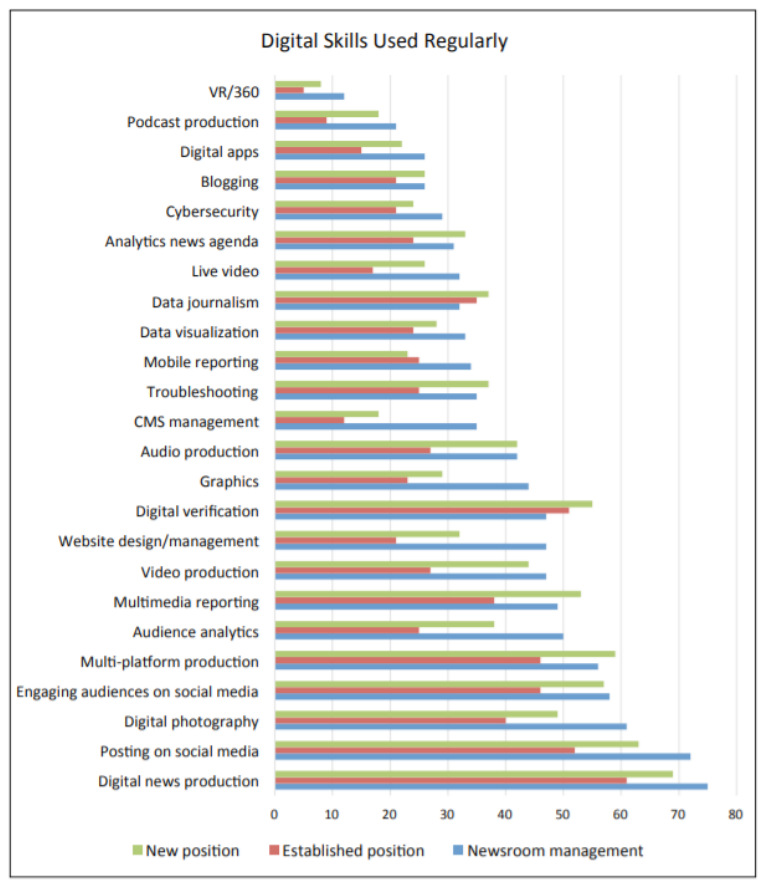

Рис.1. Цифрові технології, які застосовуються у журналістській роботі [7, p. 26].

Небажання або ж нерозуміння необхідності трансформації медійної професії виливаються у передбачення на кшталт «завершення ери друкованих медіа». У більш виграшній ситуації є редакції, які перетворили свої медіа на конвергентні, в яких завдяки інформаційним технологіям і системам комунікацій інтегруються всі види медіаконтенту в єдину систему, чим створюються нові типи медіа і платформи (веб-видання, блоги, розширення для браузерів, соціальні мережі, цифрове відео, інтерактивне телебачення, мобільна телефонія тощо) [8, с. 9]. Конвергентні медіа враховують інтерактивну взаємодію виробника та користувача інформації, який швидко реагує на медіаконтент, у режимі реального часу коментує, пропонує нове бачення проблем. Це має як переваги для виробників контенту, журналістів, фотокорів, редакторів, блогерів, так і підвищує вимоги, що включають специфічний підхід до творчого процесу виготовлення новин, форм управління комунікаційним процесом.

Все більшого значення в редакціях приділяють перевірці достовірності даних. Фактчекінг можна назвати сучасним трендом. При цьому техніки перевірки достовірності даних опановують практично всі журналісти, ця робота передує написанню статті. Адже при використанні недостовірних даних, фото, відео втрачається репутація як журналіста, так і видання. I хоча достовірність даних в соціальних мережах 
достатньо низька, більшість медіа (71\%) використовує соціальні мережі для пошуку нових сюжетів. На жаль, багато журналістів не ускладнюють себе перевіркою достовірності інформації з соцмереж, через що неправдивий контент швидко поширюється. Не можна сказати, що явище «фейкових новин» нове, адже здавна існує поняття «газетної качки», аналогом якої є навмисно неправдиві статті на базі неправдивих даних. Нині 46\% служб новин проводять тренінги з пошуку і перевірки інформації в соціальних мережах, але тільки $22 \%$ журналістів вважають це корисним.

Про цифрову безпеку все більше говорять в Україні, оскільки журналісти, які працюють в умовах військового конфлікту, наражаються на небезпеку. Міжнародні організації проводять тренінги та семінари, на яких вчать журналістів захищати інформацію на комп'ютерах і гаджетах, кодувати дані, обирати безпечні паролі, захищати дані, доступні кільком користувачам, вести акаунти в соціальних мережах, вести двофакторну авторизацію тощо. Культура цифрової безпеки журналістської діяльності, на жаль, не набула широкого поширення, багато журналістів не розуміють елементарних правил поведінки в час миттєвого поширення даних. відповідно до досліджень, 54 \% журналістів і 52 \% служб новин не забезпечують заходів безпеки своїх засобів зв'язку.

Медіа на сьогодні $є$ бізнесом, і журналісти продають новини, редакції думають про шляхи отримання прибутку, знаходять унікальні моделі фінансування. Звичайно, на першому місці як джерело прибутку є реклама (70\%), але все більшого значення набуває спонсорований контент (44\%), цифрові медіа схильні до генерування доходу з альтернативних джерел (благодійних пожертвувань юридичних і фізичних осіб), виникають краудсорсингові медійні проекти. Журналісти спеціалізуються на вузьких проблемах, наприклад, відвідування всіх судових засідань та інформування про перебіг подій. Адже не кожне медіа може на всі засідання суду відправити кореспондента, самі засідання нерідко переносяться, тривають багато годин. У цьому випадку підписка на сервіс, наприклад, «Судовий репортер», в якому оперативно та об'єктивно переповідається хід процесу, дає можливість вивільнити журналістів від перебування в залі суду.

Врахування даних аналітики відвідуваності ресурсу дає можливість публікувати матеріали в той день і час, коли є найбільше охоплення аудиторії. Хоча, за даними дослідження, менше половини новинних служб щодня перевіряють аналітику. Головним параметром ефективності ресурсу медіа вважають перегляд сторінок (73\%), набагато менше уваги приділяється параметрам взаємодії: вторинному поширенню в соціальних мережах (46\%), коефіцієнту ефективності реклами (18\%) i глибині прокрутки (16\%). Аналітики та експерти з даних прийшли в медіа із відділу маркетингу та подекуди називаються редакторами зі зростання. Редактор-менеджер аудиторії The Philadelphia Inquirer Кім Фокс наголошував, що у 2018 році медіа мусять створювати команди нового типу, які займаються розбудовою аудиторії, поєднуючи різні тактики - поширення в соціальних мережах, оптимізацію контенту для пошукових машин, аналітику, управління спільнотою та розсилки [9]. Медіа розповідають історії та інформують, бо хочуть допомогти своїй аудиторії зробити кращий вибір, бути обізнаній, змінювати своє соціальне й політичне середовище на краще. Тому питання впливу стає життєво важливим. I цей вплив може посилитись, якщо поєднати зусилля медіа і громадянського суспільства. В редакції такою діяльністю може займатись продюсера впливу, який допомагатиме редакції визначити, до чого 
покликаний продукт, який вона створює, наглядатиме за його поширенням, оцінюватиме вплив та шукатиме кошти для нових проектів.

Оскільки журналісти дедалі частіше співпрацюють із менеджерами з продукту, a Knight Center for Journalism в університеті міста Остин у штаті Техас розробив курс менеджменту продукту для журналістів [10].

Наголосимо, що журналістика вже увійшла в еру новин на мобільних пристроях. Зараз розпочинається епоха т. зв. «лінійного візуального сторітеллінга» (англ. linear visual storytelling), в якому наратив та візуальна частина подаються в лінійний спосіб згори донизу, саме так, як ми робимо, коли пишемо повідомлення у месенджерах на телефонах. Помилкою багатьох редакцій є неврахування цієї особливості. Традиційні журналістські історії із заголовком, анотацією і текстом (на зразок друкованої сторінки) не сприймаються на мобільних пристроях. Споживання новин 3 мобільного для багатьох людей стало нормою. Вони це роблять в будь яку хвилину між іншою активністю (на зупинці, в кафе, під час наради, перед сном, у відпустці тощо). Сам контент і спосіб його подачі відмінний від конвергентних медіа, і трафік тут набагато сильніший, а отже - можливості монетизації за допомогою креативної реклами, в тому числі спонсорського контенту.

Технологія стає визначальним фактором еволюції журналістської професії. Кожна інновація змінює спосіб, у який ми дізнаємося новини, а, отже, змінюється технологія створення новин. Прогнозується, що цю тенденцію продовжить штучний інтелект, що допоможе журналістам позбутися повторюваних завдань і сфокусуватися на дослідженні та репортерстві. Журналісти перейдуть на наступний рівень, вони мають навчитись працювати зі штучним інтелектом і створювати доповнену реальність.

Цифрова журналістика змінює вимоги до написання матеріалів, також заохочує журналістів постійно розвиватися і шукати нові способи подачі інформації, вимагає від журналістів нестандартного мислення в опрацюванні теми, висвітленні загальновідомих фактів. В результаті дослідження ми виявили наступні ключові тенденції, пов'язані як з трансформацією роботи журналіста, так і 3 його особистими навичками і прагненнями:

- перехід редакцій на цифровий формат, як наслідок. нестача кваліфікованих професійних кадрів;

- служби новин не повністю використовують дані і аналітику для формування контенту;

- журналісти більш зацікавлені в опануванні сучасних технологій, ніж редакції медіа;

- підвищення рівня охорони даних, захисту від хакерських атак, виявлення ботів;

- надання значення фактчекінгу;

- опанування технологій роботи з великими даними;

- врахування ролі соціальних мереж як постачальника та розповсюджувача новин;

- медіагалузь розвивається як бізнес, але недостатньо використовує всі можливі важелі;

- лінійність новин на мобільних пристроях, коли за увагу людини змагаються сповіщення, новинні додатки, соціальні платформи та новинні агрегатори;

- орієнтація на подальше впровадження в журналістську роботу віртуальної реальності і штучного інтелекту. 
Перспективи подальшого розвитку. Адаптуватись до змін у суспільстві, прилаштуватись до цифрового середовища має допомогти навчання, опанування цифрових технологій. Журналісту мало підготувати матеріал, він має розуміти, чому для розповідання історії краще підходить певний формат, як найкраще використати нові інструменти та допомогти аудиторії сприйняти контент у новому форматі. Трансформується особистість журналіста: інший спосіб мислення і звички, поєднання творчості та знань технологій збору, верифікації даних, програм створення інфографіки, монтажу відео та аудіосюжетів, опрацювання фото. Поступово відбувається перехід від відео до справжнього інтерактивного досвіду, з'являються новинні платформи із використанням доповненої реальності. Важко передбачити трансформацію журналістської професії у майбутньому. Зрозуміло одне: журналіст без знань сучасних мультимедійних технологій працювати не зможе.

\section{REFERENCES}

1. Журналістська освіта [Електронний ресурс] // Mediasapiens. - Режим доступу: http://osvita.mediasapiens.ua/mediaprosvita/education/

2. Різун В. У медійної галузі немає запиту на підготовку кадрів [Електронний ресурс] // Детектор медіа. - Режим доступу: https://ms.detector.media/mediaprosvita/ education/volodimir_rizun_u_mediynoi_galuzi_nemae_zapitu_na_pidgotovku_ kadriv/

3. Оригінальна журналістика [Електронний ресурс] // ВBC: Академія. - Режим доступу: https://www.bbc.co.uk/academy/uk/articles/art20160928165907755

4. Шевченко В. Е. Форми візуалізації в сучасному журналі : монографія / Вікторія Шевченко. К.: Видавець Паливода А. В., 2013. 340 с.

5. Henríquez C. Training is an investment, not an expense [Електронний pecypc] // Neiman Lab. - Режим доступу: http://www.niemanlab.org/2017/12/training-is-aninvestment-not-an-expense/

6. Simon B. We need better career paths for news nerds [Електронний ресурс]. - Режим доступу: http://www.niemanlab.org/2017/12/we-need-better-career-paths-for-newsnerds/

7. The State of Technology in Global Newsrooms [Електронний ресурс]//ICFJ survey.-Peжим доступу: https://www.icfj.org/sites/default/files/2018-04/ICFJTechSurveyFINAL. pdf

8. Кросмедіа: контент, технології, перспективи : моногр. / Авт. кол.: В.В.Різун, В.Е. Шевченко, Л. П. Федорчук ; за заг. ред. В. Е. Шевченко. К. : ВПЦ «Киӥвський університет», 2018. 319 с.

9. Fox K. Audience teams diversify their approach [Електронний ресурс]. - Режим доступу: http://www.niemanlab.org/2017/12/audience-teams-diversify-their-approach/

10. Product Management for Journalists [Електронний ресурс]. - Режим доступу: https:// knightcenter.utexas.edu/blog/00-18815-take-online-course-product-managementjournalists-and-learn-about-new-demand-role-news 


\title{
TRANSFORMATION OF THE JOURNALIST PROFESSION IN A DIGITAL MEDIUM
}

\author{
Viktoriya Shevchenko \\ Institute of Journalism \\ Taras Shevchenko National University of Kyiv \\ Yuriia Illienka str., 36/1, 02000, Kyiv, Ukraine \\ e-mail:victoryshe@gmail.com \\ https://orcid.org/0000-0003-1642-1283
}

The article deals with the trends transforming of the profession of journalist, provides the skills necessary for work in the digital environment. Modernity changes the requirements for the preparation of materials, encourages journalists constantly evolve and find new ways of presenting information, requires innovative thinking in exploring topics, covering the known facts, knowledge of modern technologies.

Modern journalist should be multifunctional and work in different genres. He have to master not only strictly journalistic skills but also to be technical ones. Modern journalist have to be able to edit video, photos, create infographics, verify the authenticity of non-verbal and verbal content, carry out quantitative and qualitative analysis of a large amount of data, conduct an investigation, make a story, create a website, blog, create multimedia content, protect his data and accounts.

Digital journalism encourages journalists to evolve continuously and seek new ways of providing information, requiring them to develop non-standard thinking in the elaboration of the topic, covering well-known facts. Among the revealed tendencies should be:

- Shifting editions to digital format, a shortage of skilled professional staff consequently;

- News services do not fully use data and analytics for content creation;

- Journalists are more than media editors interested in mastering modern technologies;

- Increasing of the level of data protection, protection against hacker attacks, detection of bots;

- Providing the value of factchecking;

- Mastering the technology of working with big data;

- Taking into account the role of social networks as a provider and distributor of news;

- The media sector develops as a business, but does not use all possible levers of influence;

- Linearity of visual storytelling on mobile devices, when notifications, news apps, social platforms and news aggregators are competing for human attention.

- Focus on the further introduction virtual reality and artificial intelligence into the journalistic work.

Studying of digital technologies should help to adapt to changes in society, adhere to the digital environment. The identity of the journalist has undergone transformation. He should have another way of thinking and other habits, a combination of creativity and knowledge of the technology, skills of gathering, verification, creating multimedia content etc.

Key words: digital media, journalist skills, faktcheking, analytics, big data. 